\title{
In transit :Changing social networks of sub-Saharan African migrants in Turkey and Greece
}

Citation for published version (APA):

Wissink, M., \& Mazzucato, V. (2018). In transit :Changing social networks of sub-Saharan African migrants in Turkey and Greece. Social Networks, 53, 30-41. https://doi.org/10.1016/j.socnet.2017.03.005

Document status and date:

Published: 01/05/2018

DOI:

10.1016/j.socnet.2017.03.005

Document Version:

Publisher's PDF, also known as Version of record

Document license:

Taverne

\section{Please check the document version of this publication:}

- A submitted manuscript is the version of the article upon submission and before peer-review. There can be important differences between the submitted version and the official published version of record.

People interested in the research are advised to contact the author for the final version of the publication, or visit the DOI to the publisher's website.

- The final author version and the galley proof are versions of the publication after peer review.

- The final published version features the final layout of the paper including the volume, issue and page numbers.

Link to publication

\footnotetext{
General rights rights.

- You may freely distribute the URL identifying the publication in the public portal. please follow below link for the End User Agreement:

www.umlib.nl/taverne-license

Take down policy

If you believe that this document breaches copyright please contact us at:

repository@maastrichtuniversity.nl

providing details and we will investigate your claim.
}

Copyright and moral rights for the publications made accessible in the public portal are retained by the authors and/or other copyright owners and it is a condition of accessing publications that users recognise and abide by the legal requirements associated with these

- Users may download and print one copy of any publication from the public portal for the purpose of private study or research.

- You may not further distribute the material or use it for any profit-making activity or commercial gain

If the publication is distributed under the terms of Article $25 \mathrm{fa}$ of the Dutch Copyright Act, indicated by the "Taverne" license above, 


\title{
In transit: Changing social networks of sub-Saharan African migrants in Turkey and Greece
}

\author{
Marieke Wissink*, Valentina Mazzucato \\ Maastricht University, Faculty of Arts and Social Sciences, P.O. Box 616, 6200 MD Maastricht, The Netherlands
}

\section{A R T I C L E I N F O}

\section{Article history:}

Available online 31 March 2017

\section{Keywords:}

Transnational networks

Transit migration

Personal network analysis

Network change

\begin{abstract}
A B S T R A C T
Research on the role of social networks in human migration has mainly relied on single snapshots in time. This paper focuses on the changes in composition and usage of the transnational networks of migrants and why these changes occur. It is based on ethnography and network analysis with forty sub-Saharan African migrants in two transit contexts: Turkey and Greece, over a 17-month period. Findings show that relationship preferences, resources and communication infrastructures constitute an individual opportunity infrastructure affecting how critical events produce network changes. This process is ongoing through the continued experience of critical events, suggesting that the role of networks fluctuates over time.
\end{abstract}

(c) 2017 Elsevier B.V. All rights reserved.

\section{Introduction}

Early 2009, one of us met with Senait, an Eritrean woman in her late twenties, while she was in between attempts to clandestinely cross from Turkey to Greece by boat. At that time she kept her family in Eritrea and Europe well informed about her journey. Over the following years we regularly met and kept in touch with Senait. When in 2012 we met in Athens, Senait had changed her communication patterns. She was no longer in touch with her family abroad. She would not respond to their phone calls and she had closed down her Facebook account in order to avoid contact. Yet a year later, while still in Athens, Senait's ties with her family and friends were restored, while her local network in Athens had been changing on a weekly basis. Essentially, over this five year period, Senait's social network underwent considerable changes. This paper explores why changes occur in the social networks of irregular migrants residing in transit migration hubs in Turkey and Greece. In particular, we analyse migrants' transnational social networks, that is, networks composed of relationships that are created and maintained beyond the borders of nation-states (see Editorial Introduction of this issue).

The literature on migrants' transnational social networks has highlighted the crucial role transnational social networks play in inciting and facilitating migration processes, yet the composition

\footnotetext{
* Corresponding author.

E-mail addresses: m.wissink@maastrichtuniversity.nl (M. Wissink), v.mazzucato@maastrichtuniversity.nl (V. Mazzucato).
}

of these networks is often taken for granted (Ryan et al., 2008; Schapendonk, 2014) and, in part due to a lack of longitudinal data, hardly any attention is given to the fact that they change over time (Hollstein, 2003; Mazzucato, 2009; Lubbers et al., 2010). This study contributes to an emerging literature on the dynamics of network change by investigating why migrants' networks change.

Our study was situated in the transit migration hubs of Istanbul (Turkey) and Athens (Greece). In these cities, we followed 40 sub-Saharan African informants for a period of 17 months between early 2012 and late 2013, and some up to four years starting from early 2009. Transit migration hubs in Europe's border regions differ from origin-destination contexts in which migrants' networks are commonly studied, because of their highly volatile social and institutional environment (Düvell, 2012; Wissink et al., 2013). This volatility entails critical events that bring about rapid and radical changes to a migrant's social environment, or personal circumstances. Examples of such critical events are policy implementations regarding access to asylum, continuous and sudden arrivals and departures of other migrants, or getting caught at the border by migration police. Such critical events alter migrants' ability to manage their social networks and subsequently lead to network changes.

The association between critical events and network changes is central in social network analysis (SNA), which has only been scarcely and recently applied in a migration context (Bilecen, 2016; Lubbers et al., 2010; Ryan et al., 2008). Most SNA studies aim to predict or explain specific network outcomes by assessing the characteristics of individuals, the network members, or the relationships among them. Little scholarship exists on why changes 
take place. This is crucial for understanding why, after experiencing a similar event, people's networks do not always develop in a similar way (Hollstein, 2003). Furthermore, unpacking the process of network change is essential for understanding how migration processes and networks interact. We study the process of network change by investigating the factors that affect the relationship between critical events and network changes (Hollstein, 2003).

\section{Transit migration in Turkey and Greece}

The study was situated in transit migration hubs in Turkey and Greece. Transit migration hubs are places frequently transited by substantial numbers of migrants on their way to a third country (Düvell, 2012; Papadopoulou-Kourkoula, 2008). While in the literature common reference is made to 'transit migrants', we do not apply the concept of transit to individuals because a state of being in transit can only be identified after someone has migrated elsewhere, and migration intentions fluctuate. The classification of an individual as a 'transit migrant' could therefore incorrectly presume that he or she will migrate elsewhere or intends to do so.

The concept of transit migration remains helpful to understand a context of temporal migration in which individuals shape their migration processes, but not to determine the direction and outcome of these processes (Wissink et al., 2013). A context of temporal migration entails that the presence of people can change on a daily basis; migration brokers offer their services; and policies are in place to manage onward migration. The social and institutional environment in transit contexts is therefore rather volatile, which, as we will argue, helps to understand why migrants' social networks change. A transit context is therefore a very suitable context to study network changes.

Transit migration in Turkey and Greece is often irregular in nature, which entails that parts of the migration process (e.g. entry, residence, employment and departure) are clandestine (Jordan and Düvell, 2002). In Turkey and Greece, options for sub-Saharan African migrants to obtain and sustain travel and residence documents are scarce. Turkey's application of a geographical limitation towards the 1951 Geneva Refugee Convention, means that nonEuropean asylum seekers cannot qualify for a refugee status and a permanent residence permit. Recognised refugees need to be resettled to a third country, and legally remain asylum-seekers until then (Içduygu and Yükseker, 2012). In practice, only few refugees are resettled. Asylum-seekers are appointed to reside in a 'satellite city', usually a rural town. Because asylum-seekers are not allowed to work and are usually themselves responsible for arranging accommodation in the satellite cities, many leave their satellite cities and reside in Istanbul where some find work in the informal economy.

Access to asylum in Greece is problematic: while hundreds of people line up weekly, the Immigration Office in Athens only takes 20 applications per week in consideration (UNHCR, 2012). There are no asylum seeker centres in Greece, and most asylum-seekers reside in the bigger cities of Athens or Thessaloniki. Positive decisions over cases are almost non-existent, and a second review in case of an appeal, is virtually impossible (Human Rights Watch, 2008). In both countries, NGOs have reported severe violations of migrants' rights, in particular related to indefinite periods of detention, restricted access to asylum, push-backs, and violence by state officials (Human Rights Watch, 2008; Amnesty International, 2009; ProAsyl, 2012). Notably in Greece, institutionalised and widespread xenophobic sentiments across the country further contribute to precarious circumstances for non-European migrants in the country (Wissink and Ulusoy, 2016).

In a context of dysfunctional asylum systems, restrictive EUsupported border regimes, the rules of the game pertaining to asylum and migration rapidly change. The volatile social and insti- tutional environments that characterise these two countries is manifested in migrants' daily lives through events such as constant arrivals and departures of people, arrests, displacements, resettlement, and decisions on the refugee status determination procedure.

While studies have shown that in precarious contexts where state and civil society support is weak, migrants often depend on social networks for their daily survival (Broeders and Engbersen, 2007; Chelpi-den Hamer and Mazzucato, 2010; Engbersen et al., 2006; Koser Akcapar, 2010; Suter, 2012), we expect that these events can be critical for the management of and change in local and transnational social networks.

\section{A dynamic perspective on migrants' social networks}

It is widely recognised that migrants' social networks play a crucial role in inciting and facilitating migration processes through the circulation of support. Networks inform migration plans and foreseen destinations (Faist, 1997; Fawcett, 1989; Massey, 1987), reduce the risks and costs of migration (Faist, 1997; Pries, 2004), enable the crossing of borders (Böcker, 1994), and assist with finding employment and accommodation (Boyd, 1989). In particular for migrants for whom legal channels to migrate are inaccessible, social networks have been crucial to assist them with their migration strategies (Broeders and Engbersen, 2007; Collyer, 2007; Devillanova, 2008; Koser Akcapar, 2010; Suter, 2012; Van Wijk, 2010).

Yet not always do networks explain migration processes or facilitate migration. For example, networks cannot explain migration when people migrate to countries where they did not have a network, or vice versa, when they do not migrate despite the presence of networks (Collyer, 2005; De Haas, 2010; Kalir, 2005). Furthermore, migration policies can hamper the role of networks, for example due to border controls and restrictive family reunification policies (Broeders and Engbersen, 2007). Likewise, social networks can impede instead of facilitate migration, for example when migrants do not assist newcomers due to job market competition (De Haas, 2010).

Both when networks are seen as explaining and facilitating migration as well as when they are not, there is a tendency to view networks as static and independent factors (Somerville, 2011). More recently, studies have argued that networks are both shaping and shaped by migration, suggesting that the relation between the two is interdependent (Krissman, 2005; Pathirage and Collyer, 2011; Ryan, 2011; Schapendonk, 2014). This implies that migrants' networks change as the migration process evolves. Thus in order to understand the relation between networks and migration it is essential to analyse the inherently changeable nature of networks (Lubbers et al., 2010; Ryan et al., 2008; Schapendonk, 2014).

Thus far, the changeable nature of social networks has mainly been demonstrated by cross-sectionally comparing the networks of migrants in different migration phases, such as emigration, transit, immigration, settlement, integration and return (Chelpi-den Hamer and Mazzucato, 2010; Haug, 2008; Hiller and Franz, 2004; Massey, 1987; Muanamoha et al., 2010; Van Meeteren et al., 2009). These studies show that relationships are formed in accordance with opportunities and needs associated with the particular phase of the migration process. While these studies suggest that networks change over time, their results cannot be disaggregated at the level of individual migrants to explain why their networks change over time. This would presume that migration processes of individuals, and hence the evolving of their networks, follow a predictable, step-wise development along defined migration phases. Research has shown that this is not the case: migration is often non-linear, particularly in the context of irregular migration in transit contexts (Wissink et al., 2013; Schapendonk, 2014). 
In his study of African migrants heading to Europe, Schapendonk (2014) found that timing and opportunities to connect with others contribute to the dynamics in migrants' social networks. This entails that, aside from deliberate action, luck and chance influence how social networks evolve. An unexpected encounter with someone, or being in a certain place at a specific time, can, for example, lead to changes in someone's social network, regardless of the migration phase (see also Gladkova and Mazzucato, 2016). We extend these lines of research on how and why networks change by exploring how critical events that migrants experience while in transit relate to the way relationship and network characteristics evolve over time. To this end we adopt a longitudinal research design, which only recently is becoming applied in the context of migration studies (Lubbers et al., 2010; Schapendonk, 2014).

\section{Critical events and network changes}

In this paper, we propose a framework for understanding changes in the networks of migrants in transit contexts. To this end, we draw on longitudinal personal network analysis which enables the study of network changes over time (Feld et al, 2007; Bidart and Lavenu, 2005; Suitor et al., 1997; Wellman et al., 1997; Lubbers et al., 2010).

In longitudinal social network analysis, network changes are commonly explained in relation to critical events in the personal or institutional environment of individuals (Feld, et al, 2007; Suitor et al., 1997). These events can be life course events, such as marriage and childbirth (Bidart and Lavenu, 2005), divorce (Terhell et al., 2007) and widowhood (Morgan et al., 1997; Hollstein, 2003) or societal transitions. Examples of the latter are economic recession (Suitor et al., 1997), the introduction of information and communication technologies (Dekker and Engbersen, 2014), and political transformations as studied in Russia (Lonkila, 1997), Eastern Germany (Völker and Flap, 1995), Hungary (Angelusz and Tardo, 2001) and China (Ruan et al., 1997).

Critical events have, amongst others, been associated with changes in network size, sources of support and the type of people relationships were formed with. Mollenhorst et al. (2014) explain this by the new social context such events bring forward. In transit contexts, the volatile social and institutional environment produce critical events that potentially lead to changes in migrants' networks. Examples include the continuous sudden arrivals and departures of other migrants, results of refugee status determination procedures, border control interventions, regularisation rounds, and referrals to satellite cities in Turkey. In this paper we will analyse how events as these are associated with changes in migrants' social networks.

Associations between critical events and network changes alone are not sufficient to reveal why network changes occur. After the experience of a similar critical event, people's networks do not necessarily develop in the same way. For example, after settling, some migrants may develop more local ties over time and lose contact with people abroad, while others develop more transnational ties (Portes and Zhou, 1993). Lubbers et al. (2010) found that while migrants themselves ascribed changes in their networks to the experience of events, such as change in job or marital status, this could not explain the variation in ways migrants' networks evolved. Hollstein (2003) showed that individual orientations are important for understanding the way in which a critical event, losing a spouse, determined how networks of widows evolved. Widows who were more “(social-) environment-oriented", developed larger networks than those who were not. In this paper, we aim to develop an analytical model indicating the factors that affect the relationship between critical events and network changes that occur in a transit context. In doing so, we aim to grasp the mechanisms under- lying network changes, without aiming to predict specific kinds and directions of these changes.

\section{Empirical study and methodology}

The fieldwork for this study took place over 17 months in 2012 and 2013. We also build on an earlier field study in 2009 which involved 7 of the same informants, prolonging data on their migration processes and networks up to four years (Wissink et al., 2013). Nineteen sub-Saharan African migrants in Athens and 21 in Istanbul formed the main research sample. The sample was limited to migrants from the West and Horn of Africa to allow for immersion in migrant communities during the fieldwork and some homogeneity in origin regions. The informants were approached using various gateways: in public places such as squares and markets and snowball sampling techniques. The choice for sample inclusion was primarily based on theoretical saturation where we aimed to capture variation in the variable of interest, migration strategies, in order to link these to variation in networks in a later stage of the study. We strived for an equal distribution of Horn and West Africans and men and women.

We used participant observation, in-depth interviews and social network analysis (SNA). Triangulation between these methods minimised measurement and interpretation errors, and complemented each other in reconstructing network change (Denzin, 1970; Bilecen, 2016). Nearly three decades ago, Boyd (1989) called for the incorporation of SNA in migration studies, which has since been repeated by various scholars (Boyd, 1989; Gurak and Caces, 1992; Krissman, 2005; Ryan et al., 2008; Vertovec, 2004). Still, little migration scholarship exists which includes SNA, especially in longitudinal research designs.

Participant observation enabled the identification of critical events and the observation of how social relationships were managed. Observations were conducted in public places, private houses, and common meeting points such as internet café's, call shops, restaurants and coffee houses. As the fieldwork progressed, participant observation increasingly centred on the lives of the 40 informants whom I accompanied to hospitals, NGOs, lawyers, call shops, local authorities, airports, public transport stations, churches and mosques and visited at home and in detention facilities. I further participated in numerous daily activities of a selected group of informants by selling watches and jewellery, working in sweat shops, shopping, and having dinners. These activities provided occasions to observe and experience how migrants in transit contexts create, manage, and break social relationships, and what role networks played in sustaining livelihoods. Because I repeatedly visited the same informants during different periods separated by intervals of time and maintained contact through telephone and internet in between, I was able to witness changes in their interactions and activities, and to contextualise these by considering changes in living conditions, migration strategies, and policy changes.

Semi-structured interviews were conducted to obtain the informants' own accounts of their personal social networks, which enabled the identification of what network changes were perceived as relevant. An interview guide was used which contained questions on the importance, maintenance, nature and role of various types of social relationships and the experience of critical events. The interviews further invited informants to share and reflect on their networking experiences and practices.

Informed by the literature, participant observation and in-depth interviews, a social network survey was designed to analyse the composition and structure of migrants' personal social networks. A multiple name generator questionnaire containing 15 questions on various kinds of support was developed to identify the persons 
Table 1

Field visits.

\begin{tabular}{ll}
\hline Istanbul & Athens \\
\hline January-April 2012 & May-June 2012 \\
July-August 2012 & September-October 2012 \\
May 2013 & May 2013 \\
\hline
\end{tabular}

with whom the informants exchanged four types of support: emotional/affective, instrumental, informational and financial (House, 1981; Bilecen, 2016; Amelina et al., 2012). After the survey was completed, a visualisation of the network was created by means of the software programme EgoNet (http://sourceforge.net/projects/ egonet). This was presented to each informant, with whom I discussed the accuracy and meaning of each relationship. Twelve months later, 17 informants who were still present in Turkey and Greece were invited to look at the same visualisation, and to reflect on the changes that took place in the past year, in order to identify the changes that had occurred. Informants were asked about each network member that was mentioned the year before, if he or she was still present and whether the nature of the relationship had changed. In addition to this, more general question were asked, such as whether the informant believed certain network members had appeared, disappeared, or gained or lost importance. Changes in the networks were further investigated though observation of social interactions.

The observations, interviews, reflections and the network survey were conducted during various field visits, as indicated in Table 1 . During these field visits, multiple weekly visits were paid to the informants. In between, contact was maintained through telephone, Skype and Facebook. Seven informants participated in an earlier study in 2008-2009 (Wissink et al., 2013) and contact was maintained since then.

This allowed for a longitudinal follow-up of their migration processes and changes in social networks. The aims of the research were openly discussed with the informants and consent to participate was asked. The qualitative study was based on establishing trusting relationships between me and the informants. The longitudinal design of the study enabled me to spend time together and enhance the quality of our relationship. I made sure that informants understood the purpose of the research and discussed this repeatedly over the course of the fieldwork.

Our aim was to reconstruct and explain the process of change in migrants' social networks. The results of the observations, interviews, reflections and the network visualisations were analysed in a qualitative manner. Field notes and interviews were analysed through inductive coding and compared with network visualisation and informants' reflections on the changes their networks had incurred.

The various methods complemented each other in various ways. First, as the different methods sometimes revealed different network members, a more complete image of networks could be reconstructed by combining the data from each of the tools. The social network survey focused on relationships based on clearly defined support exchanges. Other relevant relationships are herewith potentially left out but were revealed through observations and interviews. Second, discussing the network visualisations enabled the clarification of and reflections on the relationships mentioned. Third, as commonly acknowledged in social network studies, social network surveys suffer from recall problems and bias. Through observations, support relationships could be identified that were not mentioned during the survey. Triangulation thus enabled informants to explain certain additions or omissions of network members that were revealed during a particular method, making the results of other methods more accurate and interpretable.

\section{The changing networks of sub-Saharan migrants in Istanbul and Athens}

The framework we develop in this paper is based on the analysis of 40 informants. We illustrate our analysis by presenting two indepth cases of network changes in relation to critical events. The two cases were selected because they were the most variegated, allowing us to illustrate the full variety of factors found across all cases. For all cases, we assessed what factors come into play after the experience of a critical event in the production of network changes.

Mohamed is a man who directly travelled from Senegal to Turkey in 2011. Senait is a woman who left Eritrea in 2008, and arrived in Greece in the fall of 2011. Both Mohamed and Senait moved to Turkey in their 20s with the intention of going to Greece and to support their families in their countries of origin with whom both initially maintained close contact. Both developed more intense ties with a sibling in a year's time, but the process of change occurred in different ways.

Table 2 illustrates common critical events experienced by our 40 informants. Below we describe and visualise the changes that took place in the networks of the two illustrative case studies. In a second sub-section, we embed the changes in the case-study individuals' experience of critical events. In Senait's case we build on fieldwork data from 2009, when she took part in a similar study (Wissink et al., 2013). Finally, we reflect on the associations between critical events and network changes by scrutinising what factors affect the associations found.

\subsection{Changes in Mohamed's network}

Mohamed migrated in his mid-twenties from Guinea to Istanbul after his grandmother, with whom he grew up, passed away. His family had advised him to go to Europe to help provide for his younger brother. His uncle in Guinea arranged a passport, visa and flight ticket to Turkey, while an uncle in Germany would finance the journey to Europe via Greece.

Fig. 1A visualises Mohamed's network in 2012. Fig. 1B visualises the changes that took place in his network between February 2012 and May 2013. In 2012, his network mainly consisted of one component of family members in or from Guinea and another component of mostly Guinean migrants in Turkey. At that time, Mohamed maintained frequent contact with his family. He bought telephone cards or visited call shops to call several of his family members on a daily basis, mostly his younger brother and sisters and his mother's brothers. Important relationships in Istanbul included one with a local shopkeeper who allowed him to sell in front of his shop, a woman who offered him accommodation during the first months, and her husband Boubakar. Abdu was also a key person in his network; he was one of the elder Guineans in Istanbul, and his house functioned as a meeting point for Guineans. Mohamed's youth friend Amadou connects the components in Turkey and Guinea; Mohammed had lost touch with him years before, but late 2011 they coincidentally met again in Istanbul. Whereas Amadou knew Mohamed's family, they were not in touch.

In May 2013, Mohamed was still in Istanbul. An important change in his network was that relationships with people in Guinea weakened; apart from his brother and cousin with whom his relation intensified, he rarely called his family anymore. Meanwhile, Boubakar and Abdu had become more central persons in his network. Through them, he met with other, mostly elder Guinean men in Istanbul. Furthermore, his network expanded with contacts in Europe, some he knew from Guinea, and others were people he met in Turkey and had travelled onwards. The connec- 
A
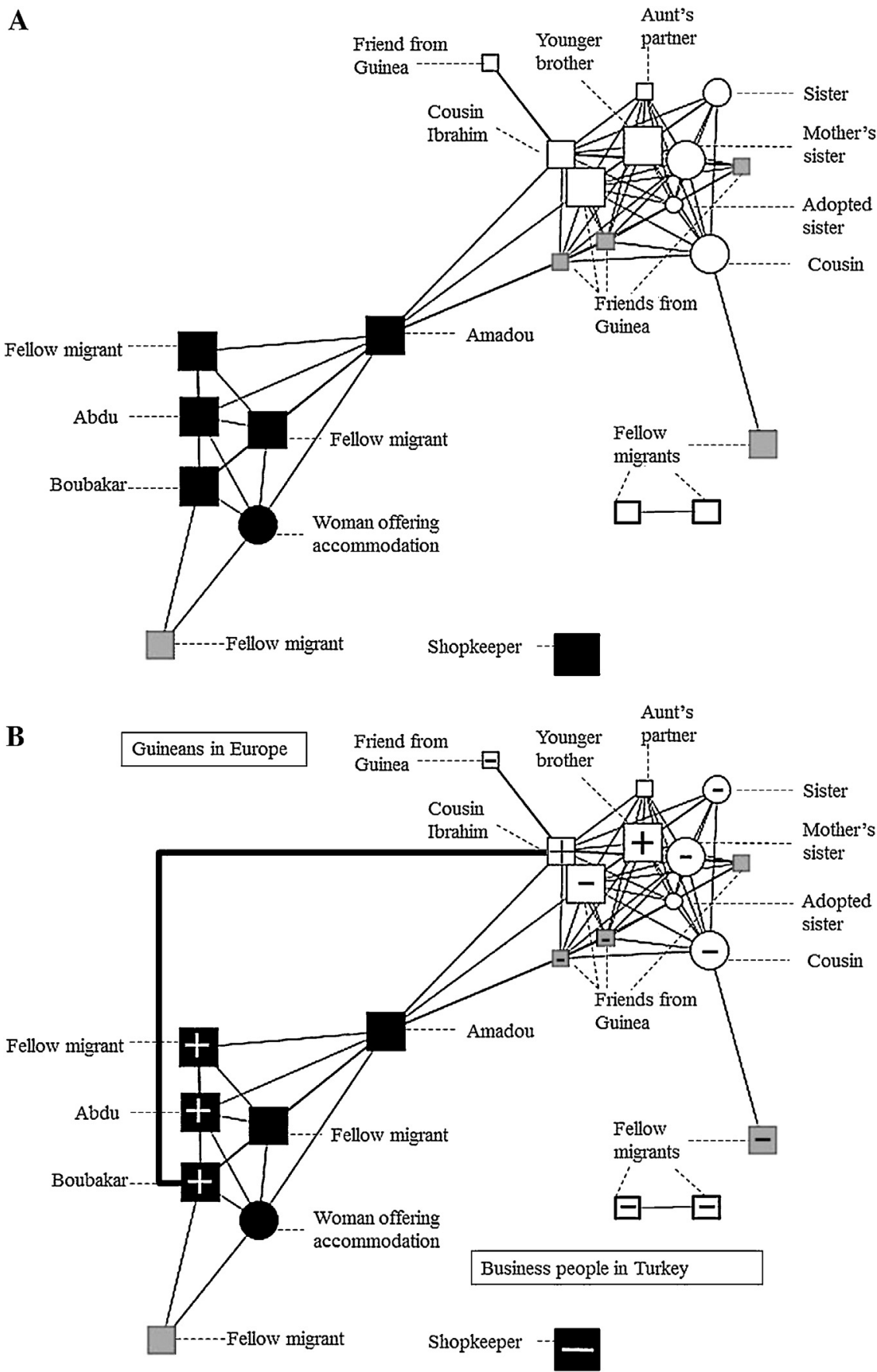

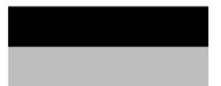

$\square$

O

Size

+ in node

- in node

No sign in node

Network member lives in country of residence (Turkey or Greece)

Network member lives in Europe or the US

Network member lives in region of origin

Male

Female

Frequency of contact (Daily/weekly - monthly - less)

Network member is more important in 2013 than in 2012

Network member is less important in 2013 than in 2012

No noted change in importance of network member

Connection is new in 2013

$a b c$

New component in 2013

Fig. 1. (A) Mohamed's network in 2012. (B) Mohamed's network in 2013. 
Table 2

Critical events experienced in transit contexts.

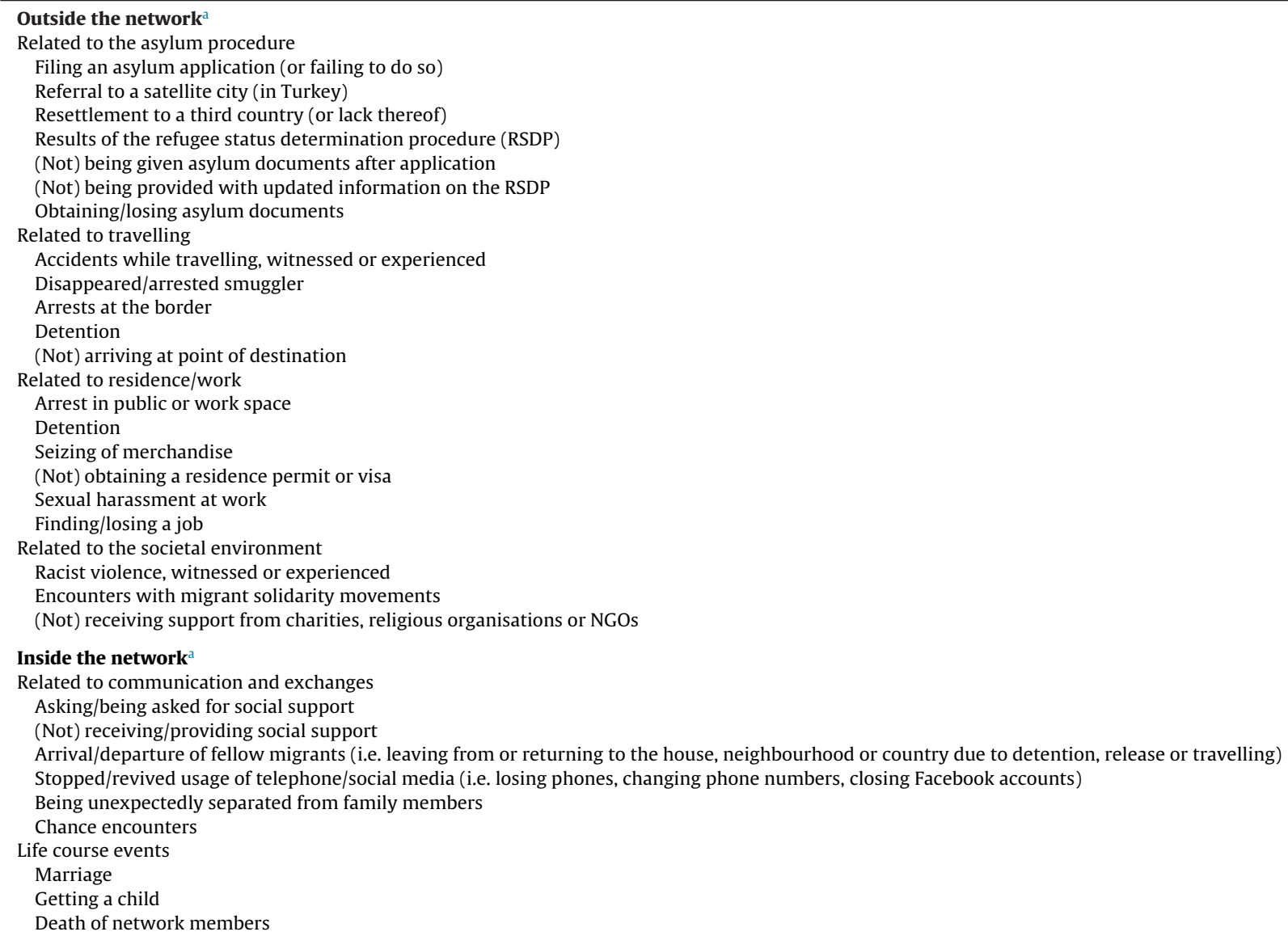

Source: Fieldwork 2012-13.

Note: This list represents common critical events experienced by 40 informants of this study.

a Events outside the network take place beyond the realm of social relationship between ego and members of his or her personal network. Events inside the network

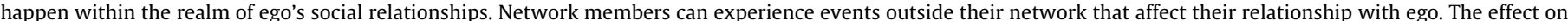
ego then counts as an event inside the network.

tion between Turkey and Guinea became stronger when Boubakar visited Mohamed's family during a trip to Guinea.

\subsection{Mohamed's experience of critical events}

We situate the changes in Mohamed's network in several critical events he experienced during a year's stay in Istanbul. Some of these events were directly caused by his social network, such as the absence of promised support from family and friends in Europe, or financial requests made by his family and fellow migrants in Istanbul involving him in business activities. There were also critical events outside the realm of social networks, including an increase in smuggler fees, growing business opportunities, a referral to a city far away from Istanbul and a termination of an asylum procedure. These are explained below.

Soon after Mohamed arrived in Istanbul, he found out that the smugglers' fees increased as a consequence of stricter border controls at the Turkish-Greek land border. Mohamed's available financial resources were not sufficient to travel onwards to Greece immediately, as he had planned. He expected to receive support from his uncle and friends in Europe, but this had not materialised. Several other informants had experienced similar critical events, which commonly changed the preferences they had regarding the maintenance of these social relationships. For Mohammed, the absence of support that was promised incited feelings of anger and disappointment. To cope with and avoid such feelings, Mohammed preferred to no longer maintain contact with people who did not keep their promises, while not providing an explanation or apology. These relationships with friends and family in Europe thus dissolved.

While Mohamed sought ways to finance his journey to Greece, his younger brother informed him about the death of his uncle and their family's need for financial assistance to organise the funeral. This event was critical, as it confronted Mohammed with his changed position in his family: being the eldest grandson, in Guinea he was always the first person to hear about big events, to inform others about these, to coordinate any possible action that needed to be taken, and to mediate in cases of disagreement among family members. Now that he was in Turkey, his younger brother had taken over this role. Mohammed had a strong preference for safeguarding his traditional position in the family as much as possible, as he still felt the same responsibility for his family as he did when he was in Guinea. This was also a source of feeling of selfworth for him. He did so by staying in frequent touch and calling daily to ensure he was informed and involved in the organisation of the funeral and to be able to give advice to his family. He used the money he earned by selling watches to make calls abroad. Sometimes this went at the cost of paying the rent, creating tensions in the relationship with his roommates. As he focused on preserving his ties with his family, staying informed and providing advice to his family, Mohamed did not invest much in creating local ties, other than instrumental relationships with the people who pro- 
vided him accommodation, and the shopkeeper who allowed him to sell in front of his house, and his youth friend Amadou. As such, he preferred to no longer give priority to establishing contact with smugglers and acquiring information about travel routes to Europe.

During the next few months, two other events were critical for the way his network evolved. The first is Mohamed's application for asylum, which included a referral to a satellite city, and the subsequent termination of the procedure. The second is Mohamed's growing involvement in Boubakar's and Abdu's cargo businesses.

Mohamed applied for asylum in order to regularise his unintended prolonged stay in Turkey. He was referred to a satellite city, about a $10 \mathrm{~h}$ drive away from Istanbul. Like many satellite cities, this city did not have an established asylum seeker community. Referrals to satellite cities in Turkey, often implied limit access to communication infrastructures due to the limited availability of internet cafes and call shops. Mohamed explained that without a "black community" he would not be able to survive. The exchange of resources, such as clothing, food and information about policy implementations among the migrant communities was essential for him to ensure his livelihood. He therefore chose to stay in Istanbul even though this meant that his asylum procedure was terminated and he became undocumented.

The event of becoming undocumented entailed that Mohamed needed to mobilise his resources in the informal sector for which he reasoned he had to stay close to other African migrants. In order to avoid the risk of getting arrested, he hardly left the city district where most migrants lived. Although police raids occurred there too, his presence drew less attention than elsewhere in the city. As such the area in which he moved was rather narrow. He spent most of his free time in a street full of call shops, a known meeting point for traders. There, his relationships with Boubakar and Abdu intensified. Boubakar and Abdu had meanwhile become successful in the cargo and textile sectors. As Mohamed had learnt to speak Turkish in the meantime, Boubakar and Abdu involved him in their business by referring their foreign customers to him for guidance and translation.

The more Mohamed got involved, the less time he could use to maintain daily contact with his family in Guinea. Moreover, he was now able to regularly send money to his family. With this new way of exchanging with his family, he had another source through which to gain respect amongst his family thus maintaining his role as a mediator and information distributor in the family was no longer a priority. Instead, he only kept contact with his cousin and brother whom he now regarded as his companions in distributing financial resources and supervising whether these were spent carefully. The nature of the relationship with his brother gradually changed and became more intense. He continued visiting call shops, but this time not to speak with his family in Guinea but to re-establish contact with people in Europe to mobilise potential customers.

In short, between 2012 and 2013, Mohamed's social network changed in terms of both the presence and nature of relationships in Turkey versus those in Guinea. This was associated with a combination of events that occurred within the realm of his network (e.g. the death of his uncle and the non-materialised support, getting involved in other people's businesse), as well as within the institutional environment (e.g. the referral to a satellite city and dropping out of the asylum procedure).

\subsection{Changes in Senait's network}

Senait left Eritrea in her late twenties, to escape from compulsory military service. She aimed to study in the UK, where her brother lived. With the help of her sister in Germany, she paid smugglers to travel to Turkey, from where she planned to travel to Greece. We met for the first time in January 2009 in Turkey. At that time, she was in regular contact with her family in Africa and Europe. Fig. 2A visualises the Senait's network in 2012. Fig. 2B visualises the changes that took place in her network between May 2012 and September 2013. In 2012, she was in Athens. Her network at the time did not include any family members or friends in Eritrea, and a few Eritrean who had already migrated. Most people in her network were Eritrean and Ethiopian migrants whom she met in Athens, or with whom she travelled together from Turkey, including Adam whom she already knew from Eritrea. The only family member she interacted with at this time was her brother's son who lived in Sudan.

While in 2012 Senait did not remain in touch with her family in Eritrea and Europe, in 2013 they were the centre of her social network. In 2012 Senait avoided contact with her sister in Germany, but they regularly spoke on the phone in 2013. At the same time, aside from a few exceptions, relationships with fellow migrants and travel companions in Greece with whom she maintained close relationships a year before, dissolved. She only follows Adam on Facebook, but they did not remain in active contact.

\subsection{Senait's experience of critical events}

Critical events that evolved from the transit context which shaped the evolution of Senait's network include lacking resettlement opportunities, failed attempts to leave Greece and confrontations with xenophobic behaviour. Critical events that took place within the realm of her social network involved requests and offers for support by her family and friends and departures of fellow migrants from Greece.

After several failed attempts to travel to Greece, Senait applied for asylum in Turkey in 2010. She was the only African asylumseeker in the satellite city she was referred to, and seemingly for many locals the first dark skinned person they had met: she faced many incidents where people pinched her skin, followed her on the street and made racist comments. Because the lack of meeting venues with fellow migrants and of accessible internet facilities, her communication infrastructure was restricted, resulting in a decline of social contact. While she was soon recognised as a refugee by the UNHCR, resettlement was not available to her. She moved to Istanbul in 2011 to reconnect with people in a similar situation and to accumulate new resources to continue her journey. Not much later, the UNHCR closed her file.

In Istanbul, she met with Adam, a friend she had known since high school in Eritrea, by chance in a neighbourhood where many migrants lived. He had just escaped from an overcrowded detention centre and persuaded Senait to try and leave Turkey once more and he offered to pay the smugglers' fees. Senait regarded moving to Greece as a chance to regain autonomy in her migration process and agreed. In Greece, Adam helped Senait in preparing their departure to another European country, but one day he succeeded alone. Months passed, in which Senait was confronted with xenophobic attitudes and police raids, during which migrants were arrested and imprisoned, sometimes for indefinite periods of time. For many migrants this meant that leaving their homes in order to meet with other migrants or to go to internet cafés and call shops had become risky, and many stayed at home as much as possible, limiting access to communication infrastructures and the mobilisation of resources, and herewith the possibility of managing networks.

While Senait was faced with challenging circumstances in Greece, she received hopeful requests for information about how to travel to Greece from friends and former colleagues in Eritrea. Senait advised them not to come to Greece, but she claimed they did not believe her. At the same time, her family continued asking questions about her travel plans, and what was keeping her from travelling to the UK. The constant requests for information were critical events taking place within her network confronting her with her precarious situation and with the fact her migration 
A

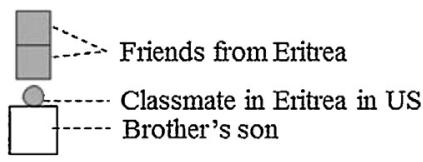

Fellow migrant met in -Turkey

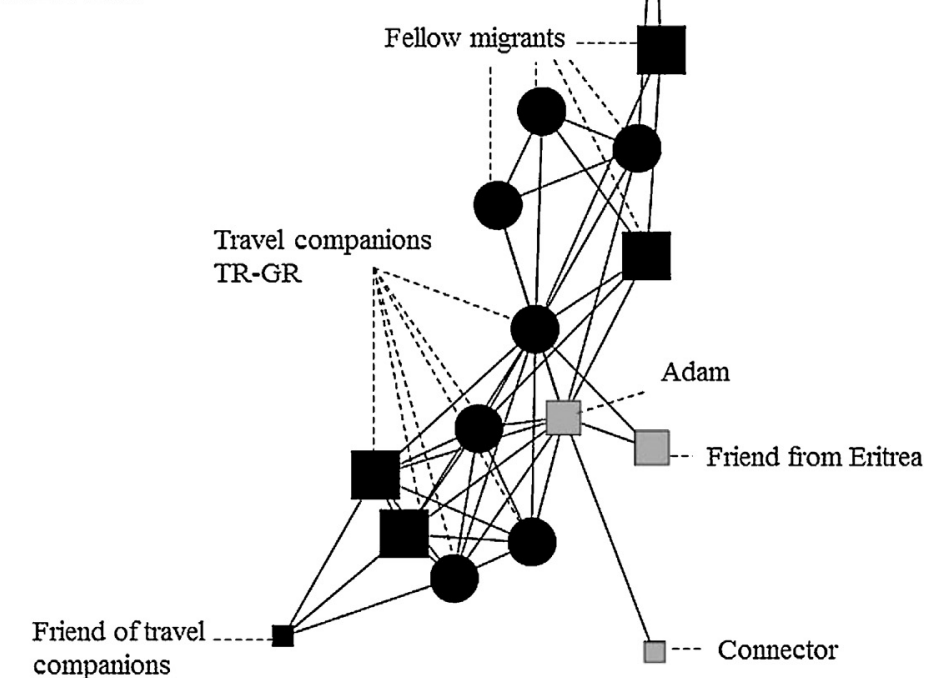

B

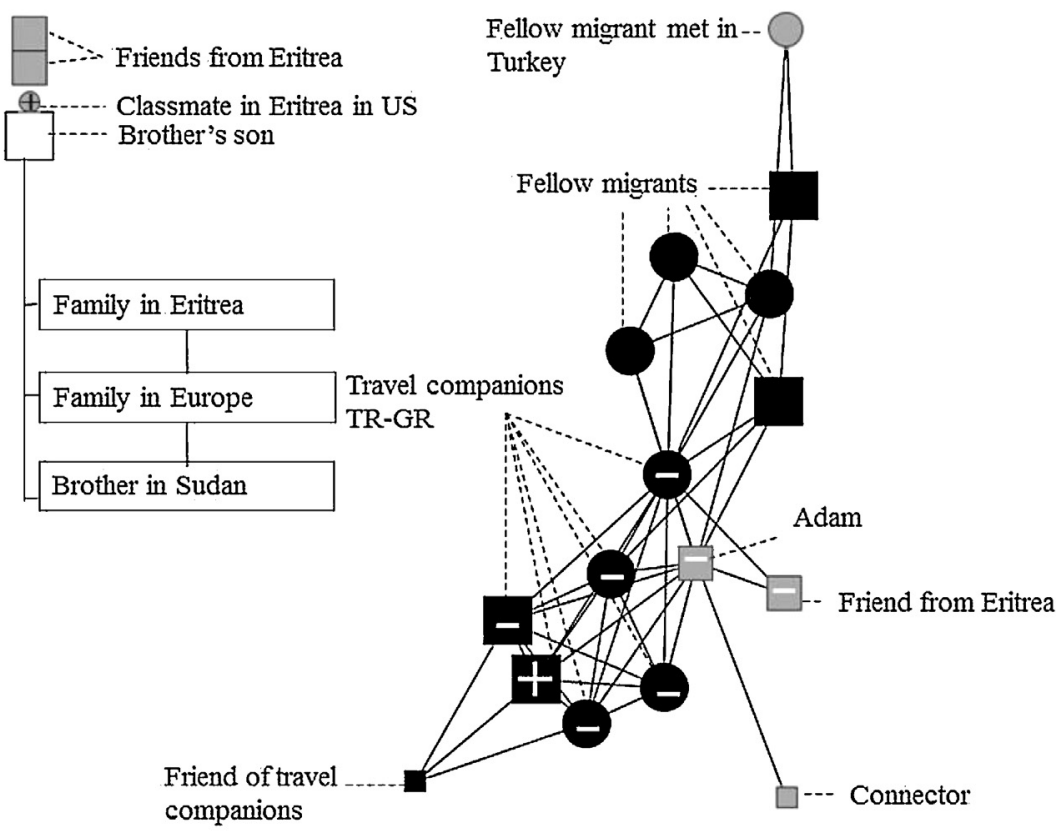

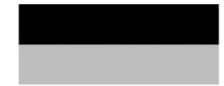

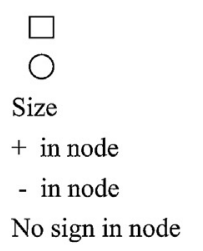

Network member lives in country of residence (Turkey or Greece)

Network member lives in Europe or the US

Network member lives in region of origin

Male

Female

Frequency of contact (Daily/weekly - monthly - less)

Network member is more important in 2013 than in 2012

Network member is less important in 2013 than in 2012

No noted change in importance of network member

Connection is new in 2013

New component in 2013

Fig. 2. (A) Senait's network in 2012. (B) Senait's network in 2013. 
project was not developing as she had hoped. Accordingly, she developed a preference to not maintain contact with her family and friends in Eritrean and Europe and closed her Facebook account and changed her phone number. She further no longer accepted her sister's financial support. The only person she communicated with was her brother's son in Sudan, as he did not ask her questions about her journey. As such, relationships with family members dissolved or weakened.

Senait's preference to retreat from contact served as a way to cope with feelings of not being able to move forward and the emotional burden it formed. On her free Sundays, she immersed herself first in the local church community and preferred creating new ties with fellow migrants over maintaining contact with family members abroad. Among them were migrants with whom she had travelled from Turkey to Greece. In sharing new joint experiences as domestic workers, with xenophobia in public places, and on the risks of getting arrested, she felt a sense of recognition and belonging, something her family could not offer her.

During the following year, most women Senait had spent her time with had left Greece. Others had been imprisoned. When she became the only one remaining from the group with whom she crossed the border from Turkey to Greece, she had more than before the feeling she was not moving forward. In a need for emotional support she preferred reviving her family relationships as she realised she could not rely on relationships with other migrants as they were not available continuously. The transiency of these relationships incited the preference to reconnect with her family, in particular with her parents in Eritrea and her sister in Germany with whom she now regularly spoke on the phone.

Thus, when critical events hampered her migration process prior to 2012 (e.g. accidents and lack of resettlement options), Senait chose to distance herself from her family to avoid questions about her whereabouts. Yet after 2012, when critical events still hampering her migration, this incited Senait to reconnect with her family for emotional support when at a time that her local relationships continuously dissolved.

\section{Individual opportunity structures}

For two cases, above we have seen how changes in networks are embedded in the experience of critical events. From the overall study, we derive three factors that explain how critical events and network changes are associated: communication venues and infrastructures, available resources, and relationship preferences.

We have seen that critical events can impact the availability and accessibility of communication venues and infrastructures, which are essential to form or maintain relationships and support exchanges (Urry, 2003). Certain critical events, such as referrals to satellite cities in Turkey, in both the case of Mohamed and Senait, constrain the opportunity to communicate when internet cafes, call shops and an established migrant community are lacking. In cases of arrests and imprisonment, communication is virtually impossible. Access to available communication venues and infrastructures can be blocked, for example when migrants limit visits to public places in order to avoid racist violence.

Critical events can further transform the availability and accessibility of resources, such as money, information and instrumental, affectional and emotional support. This may require modifying one's relationships either by maintaining, creating or dissolving them (Van Meeteren et al., 2009). We know from SNA studies that in homogenous networks, there is a limited variety in available resources (McPherson et al., 2001). Furthermore, networks in which members are not well connected, may pose difficulties in mobilising resources. Such weak ties, however, prove to be beneficial for mobilising resources beyond one's inner circle of strong relationships (Granovetter, 1973). When Senait was mostly connected with other migrants in Greece, most of whom were in a similar financial position as her, she was unable to mobilise resources to continue her journey to the UK as planned. The tie with her cousin, who was isolated in her network, proved to be highly beneficial for receiving emotional support when contact with all other family relationships at that moment were cut off.

Another crucial factor shaping the association between a critical event and changes within networks are relationship preferences. Critical events can evoke emotional or deliberate reflections on the purpose of social relationships, and herewith inform motivations to maintain, create, dissolve or alter the intensity of social relationships (Hollstein, 2003). This could for example result in wanting to concentrate on the maintenance of specific relationships only, and break with others, as was the case for Mohamed who focused on building a local network when business opportunities in Turkey expanded and he was not able to migrate further to Greece.

Critical events can further incite feelings of abandonment or encouragement, failure and success, and a need for distance or socialisation and herewith create certain relationship preferences. Senait immersed herself first in the local church community in order to socialise with fellow migrants, and disconnected from her family to avoid the confrontation with the feeling of not moving forward. Yet, when others migrated or were imprisoned, Senait reconnected with her family abroad. The meaning attributed to social relationships can thus transform when critical events occur.

The characteristics of communication venues and infrastructures, resources and relationship preferences differ for each individual, because they depend on a person's actual circumstances. This implies that the impact of a critical event on opportunities and preferences with respect to the management of social networks is not the same for each person. We therefore employ the concept of individual opportunity structure (IOS) to refer to the three factors shaping the association of critical events and network changes. Fig. 2 presents our analytical framework. This framework is proposed to explain the association between critical events and changes in the presence and nature of relationships in migrants' social networks over time. Unlike most network studies, it does not predict a certain network change. Instead, it aims to provide an analytical lens to understand why networks are dynamic in the context of migration. The framework shows that critical events lead to network changes (arrow $a$ ) because they affect the IOS (arrow $b$ ), which then impacts on the presence and nature of relationships within social networks (arrow $c)$.

There are three ways in which critical events affect changes in individual opportunity structures. First through a direct impact; for example, when critical events directly impede or enhance the access to communication infrastructures, such as arrests, imprisonments and referrals to satellite cities. Second, as a result of how migrants choose to respond to events and exert agency. This is what Senait did when she deliberately chose to abstain from using communication tools, after repeated requests for support and information by friends and family outside of Greece. Third, critical events may bring forward new constraints and opportunities that affect individual opportunity structures. For example when Mohamed became undocumented and could move around less freely in Istanbul, this resulted in the creation of closer ties with businessmen whom he chanced upon due to his restricted movement in one district of the city.

The effect of the IOS differs from person to person and over time because of interactions that takes place among the three factors that constitute it. For example, relationship preferences inform how resources and communication tools are used. Mohamed had a strong preference to preserve the type of family interaction he was used to in Guinea. He therefore spent most of his money in call shops. A need for information about asylum policies and travel 


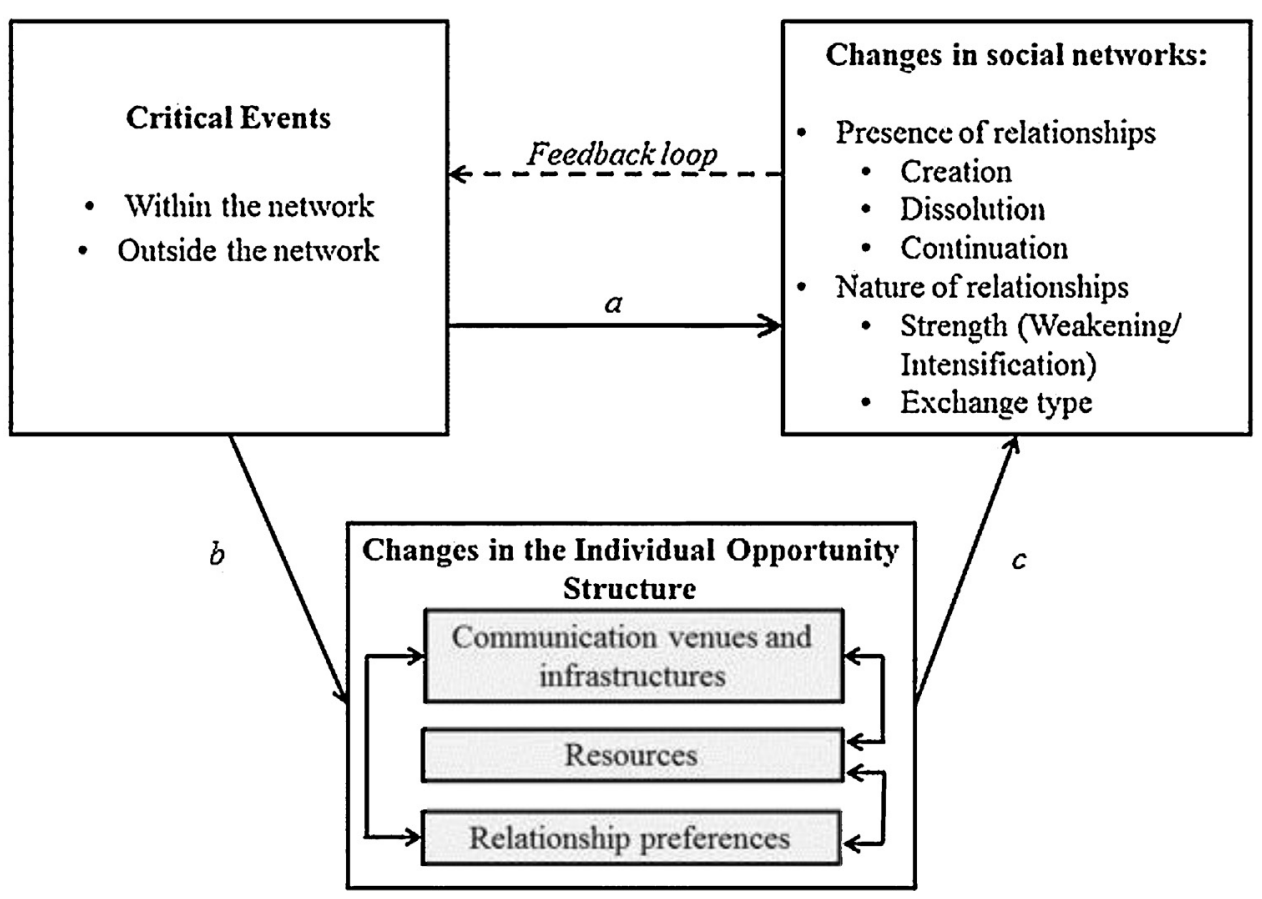

Fig. 3. Analytical framework for understanding network changes.

routes or for financial assistance incited some informants to spend hours in internet cafes to maintain or re-establish contact with friends and family members in Europe and elsewhere in the world who could provide them with these resources. Other informants developed closer relationships with local migrants when financial resources limited migrants' access to internet and call shops.

Network changes themselves can incite or constitute critical events. This is indicated by the feedback loop in Fig. 3. This is the case when a change in the network makes migrants more prone to experience certain other events, or when this directly impacts on the elements of the opportunity structure. The fact that Senait stopped contact because of the emotional burden it constituted had as consequence that she no longer received her sister's financial support. Thus, dissolutions of transnational relationships imply that certain resources that were embedded in these relationships are not available anymore. This can in turn provide a new incentive to re-establish these or other relationships. Through the continuous experience and co-occurrence of critical events, the IOS is subject to change, and so are migrants' social networks. In our analytical framework, the critical events are thus not considered as ex ante, and networks as ex post. Instead, they co-occur and co-evolve.

\section{Conclusion}

This paper analysed why changes occur in the personal transnational social networks of African migrants residing in the transit hubs of Turkey and Greece. We found that these changes occur in interaction with critical events that are brought forward by the highly volatile social and institutional environments in transit migration hubs. These critical events could take place within or outside the realm of social networks. Critical events within the realm of social networks include the departure of fellow migrants or network members refusing or initiating contact. Critical events occur outside the realm of social networks concern institutional changes, including implementations of migration policies such as arrests and decisions on the refugee status determination procedure.

Based on a combined ethnography and network analysis with forty migrants over a period of 17 months, we have developed an analytical framework to assess the association between critical events and changes in migrants' personal social networks. This association was explained by providing an in-depth analysis of two cases. These two cases exemplified the phenomena that were observed in the overall sample. Our framework explains that critical events impact on the presence and nature of relationships in migrants' networks through what we have labelled migrants' individual opportunity structures (IOS). The IOS consist of three factors: relationship preferences, resources and communication infrastructures. These factors shape whether relationships are formed or continue to be maintained, how strong they are, and what type of support exchange takes place through the relationship. The paper showed two in-depth cases illustrating how critical events evoke changes in the IOS, and lead to changes in networks accordingly.

Our findings revealed that critical events shape the IOS in three ways: First, by directly enhancing or impeding the availability of resources and communication infrastructures, for example following imprisonment or release. Second, by bringing forward opportunities and constraints through indirect or unanticipated outcomes of critical events, for example when restricted movement leads to chance encounters, which we know can be fundamental for shaping migration trajectories (Gladkova and Mazzucato, 2016). Third, when migrants are able to make a deliberate choice on how a critical event impact on their IOS, for example by accepting a loss of a relationship or resource. Our findings showed a strong interplay between the three factors: one factor could incite an increase or decline of importance of another. We further found that through the continued experience of critical events, the characteristics of the IOS fluctuate over time. This explains why the nature and presence of relationships in migrants' social networks are subject to change, too.

Because the factors constituting the IOS are continuously subject to change and interact, migrants' social networks evolve, but not according to predefined or evolutionary phases of the migration process, as conceptualised in previous migration studies (Chelpiden Hamer and Mazzucato, 2010; Haug, 2008; Hiller and Franz, 2004; Massey, 1987; Muanamoha et al., 2010; Van Meeteren et al., 2009). Studies based on such conceptualisations focus on predict- 
ing or explaining network outcomes following the experience of a critical event, or a phase in the migration process, such as arrival, integration and settlement. It is then investigated, for example, whether social networks develop in specific ways according to particular characteristics such as sex and length of stay of the migrant. One assumption often tested is whether migrants develop more interethnic and local ties as their length of residency increases (Martinovic et al., 2008; Snel et al., 2006). Instead of an explanation of network outcomes, our study investigates how changes in migrants' networks are produced. We do not aim to predict network outcomes, but rather identify elements that help to explain processes of network change. The model we develop serves the analytical purpose of distinguishing between various processes that take place when networks change.

We were able to investigate processes of network change because of our longitudinal research design, which we highly encourage for future research on network change. Longitudinal research designs enable the collection of data on network change, which does not evolve according to predictable steps. Data thus needs to be collected prospectively. While a disadvantage of longitudinal studies is the heavy time investment, the long-term character of the research design allows for the building and maintaining of trusting relationships with informants, enhancing the data quality.

One of the study's limitations is that it does not relate processes of network change to migrants' socio-demographic characteristics, such as gender, ethnicity and religion. It is likely that such characteristics shape the individual opportunity structure. A larger-scale study than this one could investigate these relationships. Another limitation is that we could only analyse changes in networks in terms of dyadic relationships, and from the perspective of our informants (ego). Further research could include the role of network structure by considering the evolving interrelationships between network members.

Despite these limitations, our analysis has implications for the understanding of how social networks change over time. First, our framework helps to understand the individual variation that exists in the way migrants manage their networks and how critical events elicit changes in networks. This in turn helps to understand phenomena that are related to network change, such as migratory decision-making. Second, in migration studies, networks are commonly conceptualised as potential facilitators of migration, where networks in Europe facilitate the migration of newcomers, while migrants in transit are driven by expectations and motivations of their families in countries of origin. This implicitly assumes that networks are static, composed of specific people who serve specific and unchanging purposes: they either help or hinder migration. Our study shows that as networks change their purpose and the expectations and motivations that shape them also shift throughout the migration process. Future research thus should not only focus on whether networks can explain migration, but rather on how the role of networks fluctuates over time due to changes in individual opportunity structures throughout the migration process.

\section{References}

Amelina, A., Bilecen, B., Barglowski, K., Faist, T., 2012. Ties that protect? The significance of transnationality for the distribution of informal social protection in migrant networks (No. 6), SFB 882 Working Paper Series. Bielefeld University (unpublished results).

Amnesty International, 2009. Stranded Refugees in Turkey Denied Protection. Amnesty International Publications, London.

Angelusz, R., Tardo, R., 2001. Change and stability in social network resources: the case of Hungary under transformation. In: Lin, N., Cook, K., Burts, S. (Eds.) Social Capital: Theory and Research. Transaction Publishers, New Jersey.

Bidart, C., Lavenu, D., 2005. Evolutions of personal networks and life events. Soc. Netw. 27, 359-376, http://dx.doi.org/10.1016/j.socnet.2004.11.003.
Bilecen, B., 2016. A personal network approach in mixed-methods design to investigate transnational social protection. Int. Rev. Soc. Res. 6, 233-244, http://dx.doi.org/10.1515/irsr-2016-0025.

Böcker, A., 1994. Chain migration over legally closed borders: settled migrants as bridgeheads and gatekeepers. Neth. J. Soc. Sci. 30, 87-106.

Boyd, M., 1989. Family and personal networks in international migration: recent developments and new agendas. Int. Migr. Rev. 23, 638-670.

Broeders, D., Engbersen, G., 2007. The fight against illegal migration: identification policies and immigrants' counterstrategies. Am. Behav. Sci. 50, 1592-1609, http://dx.doi.org/10.1177/0002764207302470.

Chelpi-den Hamer, M., Mazzucato, V., 2010. The role of support networks in the initial stages of integration: the case of West African newcomers in the Netherlands. Int. Migr. 4, 31-57, http://dx.doi.org/10.1111/j.1468-2435.2009. 00545.x.

Collyer, M., 2007. In-between places: trans-Saharan transit migrants in Morocco and the fragmented journey to Europe. Antipode 39, 668-690.

Collyer, M., 2005. When do social networks fail to explain migration? Accounting for the movement of Algerian asylum-seekers to the UK. J. Ethn. Migr. Stud. 31, 699-718, http://dx.doi.org/10.1080/13691830500109852.

De Haas, H., 2010. The internal dynamics of migration processes: a theoretical inquiry. J. Ethn. Migr. Stud. 36, 1587-1617, http://dx.doi.org/10.1080/ 1369183X.2010.489361.

Dekker, R., Engbersen, G., 2014. How social media transform migrant networks and facilitate migration. Glob. Netw. 14, 401-418, http://dx.doi.org/10.1111/glob. 12040.

Devillanova, C., 2008. Social networks, information and health care utilisation: evidence from undocumented immigrants in Milan. J. Health Econ. 27, 265-286, http://dx.doi.org/10.1016/j.jhealeco.2007.08.006.

Denzin, N., 1970. The Research Act: A Theoretical Introduction to Sociological Methods. McGraw Hill, New York, pp. 370.

Düvell, F., 2012. Transit migration: a blurred and politicised concept. Popul. Space Place 427, 415-427, http://dx.doi.org/10.1002/psp.631.

Engbersen, G., van San, M., Leerkes, A., 2006. A room with a view: irregular immigrants in the legal capital of the world. Ethnography 7, 209-242, http:// dx.doi.org/10.1177/1466138106067057.

Faist, T., 1997. The crucial meso-level. In: Hammar, T., Brochmann, G., Tamas, K., Faist, T. (Eds.), International Migration, Immobility and Development: Multidisciplinary Perspectives. Berg, Oxford, p. 217.

Fawcett, J.T., 1989. Networks, linkages, and migration systems. Int. Migr. Rev. 23 671, http://dx.doi.org/10.2307/2546434.

Feld, S.L., Suitor, J.J., Hoegh, J.G., 2007. Describing changes in personal networks over time. Field Methods 19, 218-236, http://dx.doi.org/10.1177/ $1525822 X 06299134$

Gladkova, N., Mazzucato, V., 2016. Theorizing chance: capturing the role of ad hoc social interactions in migrants' trajectories. Popul. Space Place, http://dx.doi. org/10.1002/psp.1988.

Granovetter, M., 1973. The strength of weak ties. Am, J. Sociol. 78, 1360-1380, http://dx.doi.org/10.1086/225469.

Gurak, D., Caces, F., 1992. Migration networks and the shaping of migration systems. In: Kritz, M.M., Lin Lean, L., Zlotnik, L. (Eds.), International Migration Systems: A Global Approach. Clarendon Press, Oxford, England, pp. 150-176.

Haug, S., 2008. Migration networks and migration decision-making. J. Ethn. Migr. Stud. 34, 585-605, http://dx.doi.org/10.1080/13691830801961605.

Hiller, H.H., Franz, T.M., 2004. New ties, old ties and lost ties: the use of the internet in diaspora. New Media Sociol. 6, 731-752, http://dx.doi.org/10.1177/ 146144804044327.

Hollstein, B., 2003. Netzwerkveränderungen verstehen. Zur Integration von Struktur- und akteurstheoretischen Perspektiven. Berl. J. Soziol. 13, 153-174, http://dx.doi.org/10.1007/BF03204573.

House, J.S., 1981. Work Stress and Social Support. Addison-Wesley Longman, Reading.

Human Rights Watch, 2008. Stuck in a Revolving Door. Iraqis and Other Asylum Seekers and Migrants at the Greece/Turkey Entrance to the European Union. Human Rights Watch, New York.

Içduygu, A., Yükseker, D., 2012. Rethinking transit migration in Turkey: reality and re-presentation in the creation of a migratory phenomenon. Popul. Space Place 18, 441-456, http://dx.doi.org/10.1002/psp.633.

Jordan, B., Düvell, F., 2002. Irregular Migration. The Dilemmas of Transnational Mobility. Edward Elgar, Cheltenham.

Kalir, B., 2005. The development of a migratory disposition: explaining a "New Emigration". Int. Migr. 43, 167-196, http://dx.doi.org/10.1111/j.1468-2435. 2005.00337.x.

Koser Akcapar, S., 2010. Re-thinking migrants' networks and social capital: a case study of Iranians in Turkey. Int. Migr. 48, 161-196, http://dx.doi.org/10.1111/j. 1468-2435.2009.00557.x.

Krissman, F., 2005. Sin coyote ni patron: why the "migrant network" fails explain international migration. Int. Migr. Rev. 39, 4-44, 0197-9183/05/3901.0149.

Lonkila, M., 1997. Informal exchange relations in post-Soviet Russia: a comparative perspective. Sociol. Res. Online 2, 2.

Lubbers, M.J., Molina, J.L., Lerner, J., Brandes, U., Ávila, J., McCarty, C., 2010. Longitudinal analysis of personal networks. The case of Argentinean migrants in Spain. Soc. Netw. 32, 91-104, http://dx.doi.org/10.1016/j.socnet.2009.05. 001.

Martinovic, B., van Tubergen, F., Maas, I., 2008. Dynamics of interethnic contact: a panel study of immigrants in the Netherlands. Eur. Sociol. Rev. 25, 303-318, http://dx.doi.org/10.1093/esr/jcn049. 
Massey, D.S., 1987. Understanding Mexican migration to the United States. Am. J. Sociol. 92, 1372-1403.

Mazzucato, V., 2009. Informal insurance arrangements in Ghanaian migrants' transnational networks: the role of reverse remittances and geographic proximity. World Dev. 37, 1105-1115, http://dx.doi.org/10.1016/j.worlddev. 2008.11.001.

McPherson, M., Smith-Lovin, L., Cook, J.M., 2001. Birds of a feather: homophily in social networks. Annu. Rev. Sociol. 27, 415-444.

Mollenhorst, G., Völker, B., Flap, H., 2014. Changes in personal relationships: how social contexts affect the emergence and discontinuation of relationships. Soc Netw. 37, 65-80, http://dx.doi.org/10,1016/j.socnet.2013.12.003.

Morgan, D.L., Neal, M.B., Carder, P., 1997. The stability of core and peripheral networks over time. Soc. Netw. 19, 9-25, http://dx.doi.org/10.1016/S03788733(96)00288-2.

Muanamoha, R.C., Maharaj, B., Preston-Whyte, E., 2010. Social networks and undocumented Mozambican migration to South Africa. Geoforum 41 (6), 885-896, http://dx.doi.org/10.1016/j.geoforum.2010.06.001.

Papadopoulou-Kourkoula, A., 2008. Transit Migration: The Missing Link Between Emigration and Settlement. Palgrave Macmillan, Basingstoke.

Pathirage, J., Collyer, M., 2011. Capitalizing social networks: Sri Lankan migration to Italy. Ethnography 12, 315-333, http://dx.doi.org/10.1177/ 1466138110362013.

Portes, A., Zhou, M., 1993. The new second generation: segmented assimilation and its variants. Ann. Am. Acad. Polit. Soc. Sci. 530, 74-96, http://dx.doi.org/10. $1177 / 0002716293530001006$.

Pries, L., 2004. Determining the causes and durability of transnational labour migration between Mexico and the United States: some empirical findings. Int. Migr. 42, 3-39, http://dx.doi.org/10.1111/j.0020-7985.2004.00279.x.

ProAsyl, 2012. "I Came Here for Peace": The Systematic Ill-Treatment of Migrants and Refugees by State Agents in Patras, Available from: www.proasyl.de/ fileadmin/fm-dam/p_KAMPAGNEN/Flucht-ist-kein-Verbrechen/PatrasWebversion04D-DS-k_03.pdf (accessed 28.08.14; online).

Ruan, D., Freeman, L.C., Dai, X., Pan, Y., Zhang, W., 1997. On the changing structure of social networks in urban China. Soc. Netw. 19, 75-89, http://dx.doi.org/10. 1016/S0378-8733(96)00292-4.

Ryan, L., 2011. Migrants' social networks and weak ties: accessing resources and constructing relationships post-migration. Sociol. Rev. 59, 707-724, http://dx. doi.org/10.1111/j.1467-954X.2011.02030.x.

Ryan, L., Sales, R., Tilki, M., Siara, B., 2008. Social networks, social support and social capital: the experiences of recent Polish migrants in London. Sociology 42, 672-690, http://dx.doi.org/10.1177/0038038508091622.

Schapendonk, J., 2014. What if networks move? Dynamic social networking in the context of African migration to Europe. Popul. Space Place 21, 809-819, http:/ dx.doi.org/10.1002/psp.1860.
Snel, E., Engbersen, G., Leerkes, A., 2006. Transnational involvement and social integration. Glob. Netw. 3, 285-308, http://dx.doi.org/10.1111/j.1471-0374. 2006.00145.x.

Somerville, K., 2011. Strategic migrant network building and information sharing: understanding "migrant pioneers" in Canada. Int. Migr. 53, 135-154, http://dx. doi.org/10.1111/j.1468-2435.2010.00671.x.

Suitor, J.J., Wellman, B., Morgan, D.L., 1997. It's about time: how, why, and when networks change. Soc. Netw. 19, 1-7, http://dx.doi.org/10.1016/S03788733(96)00287-0.

Suter, B., 2012. Social networks in transit: experiences of Nigerian migrants in Istanbul. J. Immigr. Refug. Stud. 10, 204-222, http://dx.doi.org/10.1080/ 15562948.2012.674327.

Terhell, E.L., Broese van Groenou, M.I., van Tilburg, T., 2007. Network contact changes in early and later postseparation years. Soc. Netw. 29, 11-24, http:// dx.doi.org/10.1016/j.socnet.2005.11.006.

UNHCR, 2012. Dozens Queue Every Week in Athens to Apply for Asylum, Available from: http://www.unhcr.org/4f6c8b6a6.html (accessed 14.07.14; online).

Urry, J., 2003. Social networks, travel and talk. Br. J. Sociol. 54, 155-175, http://dx doi.org/10.1080/0007131032000080186.

Van Meeteren, M., Engbersen, G., van San, M., 2009. Striving for a better position: aspirations and the role of cultural, economic, and social capital for irregular migrants in Belgium. Int. Migr. Rev. 43, 881-907, http://dx.doi.org/10.1111/j. 1747-7379.2009.00788.x.

Van Wijk, J., 2010. Luanda - Holanda: irregular migration from Angola to the Netherlands. Int. Migr. 48, 1-30, http://dx.doi.org/10.1111/j.1468-2435.2008. 00485.x.

Vertovec, S., 2004. Cheap calls: the social glue of migrant transnationalism. Glob. Netw. 4, 219-224, http://dx.doi.org/10.1111/j.1471-0374.2004.00088.x.

Völker, B., Flap, H., 1995. Analyses de réseaux et structures relationnelles. Rev. Fr. Sociol. 26, 629-654.

Wellman, B., Wong, R.Y., Tindall, D., Nazer, N., 1997. A decade of network change: turnover, persistence and stability in personal communities. Soc. Netw. 19, 27-50, http://dx.doi.org/10.1016/S0378-8733(96)00289-4.

Wissink, M., Ulusoy, O., 2016. Navigating the Eastern Mediterranean: The diversification of sub-Saharan African migration patterns in Turkey and Greece. Rouledge, London.

Wissink, M., Düvell, F., Van Eerdewijk, A., 2013. Dynamic migration intentions and the impact of socio-institutional environments: A transit migration hub in Turkey. J. Ethnic Mig. Stud. 39, 1087-1105, http://dx.doi.org/10.1080/ $1369183 \times .2013 .778026$ 